\title{
The Use of Ethnopedagogy in the Social \& Pedagogical Work
}

\author{
Valery Nikolaev ${ }^{1, a *}$, Elena Grineva ${ }^{1, b}$, Irina Olevskayaa ${ }^{2, c}$ \\ 1 Orel State University named after I.S. Turgenev, 302026, 95 Komsomolskaya str., Orel, Russia \\ 2 Moscow Financial and Law University, Moscow Regional Branch, 141300, 22A Moscow \\ highway, Sergiev Posad, Russia \\ awaleranikolaev@mail.ru, bgrineva2501@gmail.com, 'scorpioshka_sp@mail.ru \\ ${ }^{*}$ Corresponding author
}

Keywords: ethnopedagogical means, socio-pedagogical work, children with disabilities

\begin{abstract}
The article is devoted to the possibilities of using ethnopedagogical technologies in working with children with limited health opportunities. The psychological problems of disabled children and the ways of their prevention by means of ethnopedagogy are considered. The paper also focuses the correctional and rehabilitation potential of folk games, fairy tales, and other ethnopedagogical means.
\end{abstract}

\section{Introduction}

A number of specialists $[1,12]$ identified the following psychological problems of children with disabilities: "nervousness; pessimism; depression; fearfulness; indifference; isolation; shyness; loneliness; character roughness; mood swings; emotional instability; increased demands on others; touchiness; inability to communicate; carelessness; one-sided interests; dependency; despotism; rapid loss of interest in activities; thirst for pleasure; rapid excitability; intolerance; impulsiveness; envy; lack of sustainable professional interests" [12].

Analysis of existing research experience in practical work with children with disabilities allowed us to identify a number of their social problems: loneliness, lack of friends, lack of contact with others; the inability to attend places of entertainment (theaters, cinemas, evenings, concerts); inability to visit librararies; sometimes inability to attend school; lagging behind peers in development; few professional choices; limited leisure opportunities, etc.

After analyzing the problems of children with disabilities, researchers $[9,16]$ identified the most significant ones that prevent the full socialization of children: inability to communicate; shyness, fearfulness; a small number of contacts with others, problems of establishing relationships with others; small professional choice opportunities; organic opportunities in leisure activities, etc. [9, p. 83-84].

Disabled children are less emotional, restrained in the manifestation of feelings, experience lack of activity in emotionally intense activities. The character of a disease leaves its imprint on the emotional development and upbringing of a child with disabilities. In the normal development of the emotional sphere of the child, both feelings live in his soul, mutually balancing each other. But often one feeling dominates. Those children, who more often and more vividly experience the feeling of their strength, become stubborn and persevering, but also at the same time they become self-confident and selfish. Another picture is the development of a child who often feels his weakness, his own shortcomings, does not dare and does not dare to manifest his desires. The personality of such a child is characterized by a certain lack of complexes, shyness by psychological depression. In the guise of such a child is often read fear, timidity, stiffness, his words are cautious and indecisive actions. Such a child not only has no faith in himself, but also considers himself useless and abandoned, his mental life affirms passivity and depression, general decline and apathy, and often anger grows [9, p. 83-84].

Other forms of emotional reactions in disabled children of preschool age are irritation, anger, outbursts of rage, in which a child squeals, beats his arms and legs, or suffocates. Such seizures are most often associated either with the experience of limitations of movement, activity, or with regret because of the failure of some endeavor. Outbreaks of discontent are possible when changing a usual course of things. Correction of negative emotions, the development of the emotional and sensual sphere of these children is 
the most important concern of teachers and parents.

Studies show $[2,8]$ that ethnopedagogy plays a significant role in the emotional development of children with disabilities. Fairy tales, proverbs, songs, jokes, etc. have a high emotional potential, imperceptibly affect the child's sensual sphere. The study of ways of using ethnopedagogy during the rehabilitation of children with disabilities is highly relevant.

\section{Methodology}

The purpose of this study is to study the possibilities of ethno-pedagogical means in the process of remedial and rehabilitation work with disabled children.

Research objectives: 1) consideration of the psychological problems of disabled children; 2) identification of the possibilities of ethno-pedagogical means in the correction of their psychological problems; 3) development of a program of correctional and rehabilitation work based on the use of ethnopedagogical means. The main research methods: theoretical analysis of ethnopedagogical sources, development of a program for remedial work with disabled children using games, fairy tales, songs, proverbs, etc., monitoring the influence of ethnopedagogical means on the emotional sphere of disabled children.

\section{Study}

Practice, special studies have proven the effectiveness of the use of ethnopedagogy in social and pedagogical work. This is caused by a number of circumstances: a) it is little affected by ideology, conjuncture, b) ethno-pedagogical means have a complex effect on consciousness and behavior, c) ethnopedagogy is highly humanistic [8].

As the study of excellence shows, a game is an effective means of rehabilitating a disabled child, developing his physical, emotional, and cognitive sphere. "Participation in games allows one to quietly form his moral qualities, abilities to understand the other, to develop partnership, cooperation, self-restraint" $[9, \mathrm{p}$ 98]. A child starts playing from the infant period, when the first games are pestushki, poteshki, jokes. According to psychological research (A. N. Leontyev, A. V. Petrovsky, S. L. Rubinstein, D. B. Elkonin, etc.), a game is the leading activity of preschool children, that is, contributing to the development of the child's main mental abilities. Games are the most important means of socialization of a preschooler, his physical and moral development. Psychologists define games as "the re-creation of human activity, in which its social, actually human essence - its tasks and the norms of relations between people" stand out from it [17, p. 62]. In a game, the child develops human relationships emotionally and through the cognitive sphere.

According to special studies, an important place in the development of the motor sphere of preschoolers with speech defects is played with choruses, which are based on a round dance [5, p. 49]. In the practice of working with children with disabilities, it is advisable to use such games: "Repka", "Karavai", "Kostroma", "Kolpachok", "Went a goat through the forest", "Baba sowed peas", etc., which stimulate children's movement and speech motivating them to clearly and clearly pronounce the chorus text or sentence. Games with choruses contribute to the development of the rhythmic-melodic side of words, eliminates mixing of case endings, improves the coordination of verbs and nouns.

A significant place in the work of children with disabilities is assigned to didactic games, differentiated by the nature of the material used into three groups: 1) subject, 2) board games, 3) verbal [7, p. 176]. Subject games include games that use didactic toys and materials (cubes, pyramids, prefabricated toys, etc.). With their help, fine motor skills develop, color discrimination improves, children learn to relate the sizes of objects. Table games based on the selection of pictures: lotto, mosaic, puzzles, etc. have significant potential. During the games, children learn numbers, letters, practice counting, they form the beginnings of logical thinking.

According to special studies (P. A. Bogdanova, M. G. Evgrafova, T. A. Repina, M. A. Stepanova, and others), verbal and speech games enrich the vocabulary of children, stimulate their speech activity, the implementation of the planning and regulating functions of speech, help them master the form, meaning of words, sentences [4, c. 70]. In the course of these games, children are forced to enter into role relationships, 
use different types of speech (playing, correcting, summarizing, etc.), plan and comment on the course of the game, evaluate participants' actions.

According to the results of special studies (E. N. Totskaya and others), a significant potential of mobile games for the development of physical, communicative abilities of children with disabilities was revealed. There are three groups of outdoor games, according to the number of participants: 1) individual, 2) doubles, 3 ) team games [14, p. 85]. Before a game starts, it is important for children to agree on the choice of game, to attract other children to participate in it, and to determine the rules. These games develop the ability to interact, cooperate with teammates, train in agility, mobility, and stimulate physical activity. Success in outdoor games gives children with disabilities confidence in themselves, increases self-esteem.

Such an ethno-pedagogical source as poteshka enjoys considerable popularity among younger children. It is a word game, fun, which is shaped like verdict songs that organize these funs [6, p. 41]. Initially, the poteshki were designed to amuse children, and they were accompanied by playful actions.

According to the research data, the poteshka game attaches the child to the game, develops a need for it, lays the foundation for game activities, prepares for collective games. Famous Russian doctor and popularizer of national games, E. A. Pokrovsky called the poteshka game "the school of the game" [10], designed to prepare for participation in more complex games.

The analysis of the contents of the poteshka game showed that they have a certain rhythm that organizes its content. In order to maintain joyful emotions, jokes and comic motifs are included in the litters [6, p. 42]. Popular nowadays is the cue: "The goat is horned / For the small guys. / And whoever does not drink milk, / They will stop, will stop!" [6, p. 174]. The adult's "goat's" fingers tickle the child slightly, making him laugh and have fun. For the success of remedial work, it is important to seek children's involvement in the process of the game.

As the analysis of the texts of the poteshki game shows, they stimulate the child's cognitive activities. To do this, they include information about the surrounding world, in particular, the concept of an account is introduced on specific images. Specific objects appear as a countable rhythmic unit: "fingers," "child," "sorochata," etc. These are the first attempts to teach generalization, abstraction to children [6, p. 43]. But the poteshki game is built so that knowledge is not given in a finalized form. A child must perform a series of mental operations to acquire them.

One of children's favorite genres of folklore is traditionally a fairy tale. Correctional work based on a fairy tale involves reading them by a teacher, retelling children in roles, staging, inventing a new finale, including new heroes, etc. Understanding the shades and plot of a particular fairy story enriches the emotional sphere of a child, contributes to the development of his thinking, speech. An in-depth work with a fairy tale expands the child's vocabulary, in particular with adjectives that reflect characteristics of such characters as "a stupid bear", "a sly fox", "a brave rooster", "a cowardly hare", etc. [3, p. 105]. The process of remedial work with a fairy tale is important to bring to the children's perception of the emotional background of a fairy tale, to ensure understanding of its content, moral and pedagogical ideas embodied in it.

In the experience of correctional work with a fairy tale, experts recommend the use of special techniques that affect different parts of the brain. The most effective methods are: drawing scenes from fairy tales, modeling fairy-tale heroes using from clay, making "magic" objects, various creative tasks [11, p. 60].

According to psychological research (L. S. Vygotsky, A. N. Leontyev, D. B. Elkonin, and others), for a preschooler a fabulous, imaginary world is adequate to the game situation; therefore, it cannot be separated from his real life. A child, due to age characteristics, makes it easier to understand actions of fairy-tale characters than real people. A disabled child needs less willful effort to repeat words, actions, rehabilitation exercises after the heroes of fairy tales. This allows to reduce the level of emotional stress, to overcome communication barriers, that is, to humanize the correctional and rehabilitation process. Best practice confirms that conducting classes on behalf of Emelya, Petrushka, Neznayka, and other fairy-tale characters turns remedial work into a fun, entertaining, informative game. Children are invited to "teach" a fairytale hero to correctly perform one or another action, pronounce various phrases, words.

According to observations, the motivation of children in such classes is much higher than when they 
have to repeat the exercises for adults. If there is a fairytale character at the lesson who needs to be taught something, then a child becomes in the position of a responsible, older. According to psychological research, putting a child in the position of a senior educator largely motivates his moral and mental powers [13, p. 4043]. Psychologists have found that the child has a need to participate in the life and activities of adults. To become more knowledgeable, experienced, even for a fairytale hero, this is the realization of this need, which increases the child's self-esteem, brings him closer to an adult, and stimulates him to actively work on speech disorders.

Research has established $[15,16]$ that the rehabilitation effect of folklore means is based on changing the emotional background of the life of a disabled child from negative experiences, on a funny, dreamlike environment. "As a result, the mechanisms of therapy with joy and creativity, self-expression are included" [15, p.p 11-12].

To create a full-fledged technological support of ethnopedagogical impact on sick children, it is necessary to give leading characteristics of the technology. These include: phasing, consistency, operational, procedural, and repeatable. Most ethnopedagogical sources (proverb, fairy tale) are not technological by themselves. The exceptions are games, ceremonies, holidays, etc. These are complex sources of national education. They originally incorporated technology. However, without special pedagogical interpretation, accompaniment, neither the game nor the holiday can fully perform all their pedagogical functions.

The universal technology of inclusion of ethnopedagogical sources in the correctional and rehabilitation process is the technology of collective creative activity. The stages of implementation of this technology are highlighted: 1) preliminary work of teachers, 2) collective planning, 3) collective preparation, 4) implementation, 5) collective analysis, and 6) after action [8].

The content of this technology with ethnopedagogical sources gives a number of effects: a) technologization of rehabilitation work, b) emotional filling of social and educational activities, c) creation of conditions for the activity of disabled children.

On the basis of these packages, a rehabilitation program for children with disabilities, used in summer camp conditions, was developed. The purpose of the program was to create a folk-gaming space with a rehabilitation potential. Tasks of the program: 1) diagnosis of the socio-psychological problems of children with disabilities; 2) the creation of a folk-gaming space; 3) the inclusion in the rehabilitation process of healthy children and adolescents; 4) the organization of collective creative activity based on folklore material; 5) identification of the effectiveness of rehabilitation work.

Directions of the program implementation: 1) educational and rehabilitation measures based on ethnopedagogy; 2) conducting trainings on the material of folklore; 3) organization of circles on folk culture. The use of ethnopedagogical sources in the process of rehabilitation of children with disabilities during their stay in the summer recreation complex is implemented in the following ways: 1) the formation of the ethnopedagogical theme of the camp shift; 2) the use of ritual and festive forms of events; 3 ) orientation of the whole work to family-living, traditional-national values.

\section{Conclusion}

Analysis of observations of children, conversations with them, and their parents showed that the use of ethno-pedagogical sources as a rehabilitation tool had a positive impact on children with disabilities. Significantly improved the emotional sphere of program participants. At the beginning of the shift, children with disabilities were greatly depressed by the new situation, they missed the house, many often cried. There was a weak interest in any activities. Children often were capricious, refused to participate. The special emotional atmosphere created by folk games, fairy tales, songs, epics gradually enticed them. The use of ethnopedagogy has positively influenced the development of the physical, emotional, communicative spheres of disabled children. By the end, children became much more active in communicating with each other, healthy children, and adults.

The identified positive changes in the emotional, personal spheres of children with disabilities convince of the high importance of the use of ethno-pedagogical means in their socio-psychological rehabilitation. 


\section{References}

[1] Akatov, L. I. (2003). Social rebalancing of children with disabilities. Psychological foundations: Textbook. Moscow, Russia: VLADOS.

[2] Blinkov, Yu. A., Gubarev, E. A., \& Chernykh, A. M. (1999). Basics of the formation of a full-fledged life activity of children with disabilities. Kursk, Russia: Publishing house of KSMU.

[3] Gracheva, O. N. (1999). The use of Russian folklore for the development of the emotional sphere of hearing impaired preschoolers: Dis ... Cand. Sciences. Moscow, Russia.

[4] Evgrafova, M. G. (2003). Forming a culture of speech communication of senior preschoolers by means of ethno-etiquette: Aut. Dis ... Cand. Ped. Sciences. Yakutsk, Russia.

[5] Zhukova, N. S., Mastyukova, E. M., \& Filicheva, T. B. (2000). Speech therapy overcoming the general underdevelopment of speech in preschoolers. Ekaterinburg, Russia: Publishing house LITUR.

[6] Melnikov, M. N. (1987). Russian children's folklore. Moscow, USSR: Enlightenment.

[7] Nikolaev, V. A. (2011). Ethnopedagogy. Tutorial. OGU, Orel, Russia: OGU.

[8] Nikolaev, V. A., \& Usoltseva, E. V. (2018). Pedagogy, 6, pp. 84-92.

[9] Pashkov, A. G., \& Goneev, A. D. (1999). Pedagogical foundations of social rehabilitation of children with disabilities. Kursk, Russia: Publishing house of KSMU.

[10] Pokrovsky, E. A. (1887). Children's games. Mainly Russians (in connection with history, ethnography, pedagogy and hygiene). Moscow, Russia: Typography A.A. Kartseva.

[11] Semenova, T. N. (2010). Formation of readiness of future pathologists to use the potential of national pedagogy in speech therapy work with preschoolers: Dis ... Cand. Ped. Sciences. Cheboksary, Russia.

[12] Social household and labor rehabilitation of disabled people. (1997). Moscow, Russia: Social Health of Russia.

[13] Subbotsky, E. V. (1991). A child opens the world. Moscow, Russia: Enlightenment.

[14] Totskaya, E. N. (2011). The directional impact of mobile games on the development of communication skills of children of senior preschool age: Dis ... Cand. Ped. Sciences. Volgograd, Russia.

[15] Shpanko, E. Yu. (2001). Socio-pedagogical rehabilitation of children with disabilities by means of Russian folklore: Author. Dis ... Cand. Ped. Sciences. Moscow, Russia.

[16] Yarskaya-Smironova, E. R., \& Naberushkina, Z. K. (2004). Social work with the disabled. St. Petersburg, Russia: Peter.

[17] Elkonin, D. B. (1978). Psychology of the game. Moscow, USSR: Pedagogy.

[18] Uskov, V. L., \& Uskov, A. V. (2007). Advanced Technology for Learning, 4, 3, pp. 118-125. 